\title{
Machiavellian Nation-State Ideology as a Democles' Sword over Culture Policy of the EU
}

\author{
Alper Çakmak \\ Süleyman Şah University/istanbul \\ Email: acakmak@ssu.edu.tr
}

Doi:10.5901/mjss.2014.v5n23p1956

\begin{abstract}
The paper is set out to examine the relationship between working nation-state paradigm in European Union member countries and its effect on the culture policies of EU members. What is aimed here is that the obstacles against a common culture policy in EU ache, is a reminiscent of nation-state reactions which can be explained through the understanding of Machiavellian philosophy of state. The mechanisms of the nation state function in parallel with the Machiavellian "ruthlessness" when it comes to the development of common culture policies since culture is s 'securitized' and thought to be bounds of the imagined community that should not be violated in any case. There is a sense of Machiavellian submission of the religion in coherence with the 'ends' of the state and the formation of subordinate, god fearing citizens who compose the imagined community in his philosophy. Nation-states have been endeavoring to trash off the diversities to create a new conception of unitary and artificial community whose members are implicitly forced to be subordinates and objects of 'national culture' so that just like in Machiavellian vision, they are easy to control. The prominent tool in the mechanism of subordination is the 'institution of citizenship', which is directly identified with the notion of having equal rights and the sense of having equal right is directly associated with having the same identity. The deepening process of European Union was expected to create various realms commonalities such as strengthened political union in terms of fiscal and culture policies but it has not been the case so far. The paper tries to put light on the question why member states are still in conflict in culture policy, obstacles against founding a new common culture policy which are crucial since the problematic mechanism still prevents the EU from becoming "People's Europe". The Machiavellian philosophy will be utilized to show what kind of parallelisms are working in the complex, multifaceted problem of legislating a common binding culture policy in the era of "imagined communities" since the philosophy still functions as an "invisible preventive hand" and questions whether it is able to give a viable response to the EU common policy programs.
\end{abstract}

Keywords: European Union, culture policy, Machiavelli, nation-state, globalization, imagined community;

\section{Introduction}

There are two theoretical basis, those of globalists and realists upon whose theoretical frameworks, the relationship between the nation-state paradigms and globalization is to be interrogated. These theoretical bases are of significance in unfolding European Union's cultural policies during the globalization process. The article is set out to interrogate globalization's effect on the nation-state paradigms and explores European Union (which is also going to be categorized as a 'reminiscent of nation-state realm') and how its cultural policies make allusion to "Machiavellian patriotism embodied in the member states of EU acting only in self-promotion, independent of any consideration of good or evil" in the process of globalization (Deutsch 2004, 192). Globalists and realists' differing views are going to depict which of the theories mentioned is more explanatory and applicable to the case of European Union when the real-life implementations are the case. The kinds of parallelisms that can be drawn between Machiavellian philosophy and the real-political implementations of EU member states are more evident in the realm of cultural policies. The aim is to point out the reciprocal relationship since European Union is neither an agent nor the object of the process but one part of it reacting, responding and circumventing. While engaging with EU's cultural policies and globalization process as an antiMachiavellian force, the paradigms (Eurocentrism and Multiculturalism) adopted by European Union in order to appease people's growing needs will be interrogated in order to point out the ideological and implementational responses of EU whose members' Machiavellian nature implies a sense of "collective selfishness" of member states (Deutsch 2009, p.192). On the one hand the realists elaborate that

"Globalization can progress only as far as national policy makers will allow. But if integration is a deliberate choice rather than an ineclutable destiny, it cannot render states impotent. Their potency lies in the choices they make"(Wolf 2001,p.183). 
On the other hand, globalists' view can be associated with the total submission and dismantling of nation statesystem as pointed out with Robinson's words;

\begin{abstract}
"The various efforts in sociology and political science to grapple with globalization are prepared to admit the emergence of a world economic system but are unwilling to admit the possibility of the ultimate disintegration of nation-states and national cultures" (Robinson 1998, p.572).
\end{abstract}

In order to examine European Union's culture policy and its reciprocal relation with globalization process, it is crucial to take consideration of the nation-state paradigm. So as to unfold the globalization and its effect on the individuals forming the nation-state communities, Dijkstra, Robinson and Morris (1998) contribute in the assessment of the relation between globalization and individuals' cultural identities. Each community is built upon the individuals who are different from each other. They differ in many aspects such as: ethnicity, culture, religion etc. Since the state-system of Westphalia was established, the term nation state emerged on the stage where the cultural diversity has been perceived as the bacteria to be disposed of, if not, to be reduced. Robinson (1998) unfolds the nation-state system as an historical event, dating back to 500 years or more, in parallel with the transition of Europe from feudalism to capitalism, which has its own unique national markets, structures of production and polities. The emergence of national economic structures depended upon the territory upon which the nation-states rely, made people derive of their subjective identities from their sense of geographical space (from nation-state's limited territorial space) and with an utter clash between their own subjective identities and the life based upon material coordinates during the period called pre-globalization. Nation-state period of history created a Sorelian myth of 'nation' whose artificial features can be expressed with the term imagined community (p.567). Imagined community is the key term since its implications make a further reference to the Machiavellian notion of "patriotism as the highest good and ultimate justification for the prescription of evil" (Deutsch 2009, p.192)

\title{
2. Machiavellian Imagined Community and EU Member States
}

The term nation-state created a 'natural' (in fact artificial and imagined) connection between what is called nation and the state. What is the prominent suggestion is that 'nation' is the whole members of the society living within the borders of the state and they are just 'objects' subjected to the ideology of nation-state through mechanisms of the state (real subject or agent). The mechanisms of the nation state function in paralel with the Machiavellian "ruthlessness" when it comes to the cultural issues (that are thought to be bounds of the imagined community that should not be violated in any case) such as religion or identity. There is a sense of Machiavellian submission of the religion in coherence with the 'ends' of the state and the formation of subordinate, god fearing citizens who compose the imagined community in his philosophy. In very paralel with the notion, "the problem is manifest in the way the terms state and nation are used almost interchangeably in a nation-state paradigms and the conflation of the nation state with society"(Robinson 1998,p.565). As claimed by Dijkstra (2001) the state and the political community came to be equated increasingly with the 'national culture' (p.56). Nationstates have been endeavouring to trash off the diversities to create a new conception of unitary and artificial community whose members are implicitly forced to be subordinates and objects of 'national culture' so that just like in Machivelli's vision, they are easy to control. The prominent tool in the mechanism of subordination is the 'institution of citizenship', which is directly identified with the notion of having equal rights and the sense of having equal right is directly associated with having the same identity. Dijkstra makes his point with the words of "citizens are members of the nation and acquire equal rights within a certain state must therefore also be equal to all others in that state: citizens must have the same identity. As to elaborate on the identity and culture as a means to the end, "use of religion to either manipulate or placate the people" is one of the means in Machiavelli's philosophy that indicates the association of the state-citizen-cultural identity nexus (Deutsch 2004, p.216). The ideal of equality is thus linked to possession of cultural identity"(Dijkstra 2001, p.57). Globalization functions as the catalyst for the emergence of 'new' identities or cultures. Though 'new' is the term chosen here, it is not chosen to imply the sense of being recent. The 'new' identities or cultures emerging with the process of globalization are 'new' to the ideology of nation-state system since they have been overlooked, trashed off, subordinated or disposed of in order to create what Dijkstra calls 'imagined community' that is in compliance with the selfish, self-interested and self-help territorial system governed by nation-states. Policy makers need to be as powerful as "a lion" and as cunning as "a fox" in order to trash off the cultural differences that are not state-serviant. Dijkstra explains the reciprocal relationship between globalization and nation states by claiming the world's becoming smaller in paralel with every passing day and calls it a global village where people and places cannot be sepereated by boundaries and become mingled and linked to each other. Therefore, it is of ultimate significance that cultural globalization that is 
reflected throughout the paper stands just in opposite to what many social scientists argue as "McDonaldization", and rather it refers to people's growing links with their original identities through the growing opportunities such as media and tourism etc. Mutual relations of dependence and (increasing number of) intensification of interactions between increasing number of subjects prevail and govern every day life. Upon this ground, the transition of multinationals to transnational 'global' organizations is the case. Via tourism, the media and consumer goods, people from each society encounter and find themselves engaged in other cultures and aspects of other societies. By means of breakthroughs in communication, technology and transport, monetary mobility, notions and people can be transfered at a high speed (Dijkstra 2001, p.64). Globalization here is the agent working against the typical citizen provisioned by Machiavelli's philosophy.

The traditional notions of family, community, church have been utilized to create the 'imagined community' as the basis of the nation-states. Hence nation-state emerges as the entity identified with the territorial space and an 'imagined community' whose members are mobilized with the notions of family, community and church. "Judging the presence of Christianity from the perspective of its political usefulness" is the cornerstone notion in Machiavelli's philosophy since "Machiavelli praises Ferdinand for his keen understanding of popular sentiments toward religion, as well as, his willingness to exploit them for political purposes" that points out the parallelism between the nation-state ideology and Machiavellian philosophy (Deutsch 2004, p.216) It does not take a genius to deduce that members of 'imagined community' are subjected to become the subjects of the common territory on which nation-state's sovereignty prevails and the relationship between the people and territory becomes more obvious since people are utterly made part of nation-state's functioning mechanism and has as much significance as the territory of the nation-state not for it is a virtuous must but for "necessity's sake".

"As a result of the interaction between local and global elements and mechanisms, new multiple and varying identities emerge. These identities are no longer confined to a specific area-they are deterritorialized" (Dijkstra 2001,p.58).

The diminishing borders opened the way for the movement of cultural forms which is directly in opposition with the nation-state system whose cultural boundaries function to preserve 'imagined communities' existing within the territorial space. Nation state paradigm falls short of embracing the fact that identities of people cannot be confined to limited domains of the nation-states such as; territory, community and rigid borders. Dijkstra makes the claim that diminished cultural boundaries pave the way for rebirth of 'nationalism', 'regionalism', 'ethnicity realization' and 'cultural differentiation within national societies ' (p.58). Multiple identities emerge through the process of globalization since members of imagined community (whose origin does not and cannot feed on the imagined community of nation-state) are exposed to different cultures and more importantly the migrants or people of different origins are given a crucial incentive to realize the essence of their individuality and in that point of realization, they are completely deterritorialized and their connection or sense of belonging to the nation state is questioned when their links to the outside world functions in compliance with how they live in their daily lives. Robinson's (1998) words make a summary of the general picture; the system of modern world has advanced through respective phases of 'global interconnections', each one deepening webs of links and further tore down the local, national and regional autonomies. The qualitative transition created by globalization is the circumvention of the nation state that is supposed to be the prominent form of social organization. Though this progress has broken through many phases, it is not complete yet and needs to advance furthermore.

Deterritorialization of people provides the realization of the fact that the 'imagined community' system functions, in fact, as a covet over the multicultural society since it is perceived as a threat to the national security of the nation-states and it is feared whether such a realization undermines the sense of belonging to the community which is what most prominently is in service of the nation state system. Machiavelli's proposal of "cloaking himself in the garb of the faith, to sanctify his political ambitions" is made for the princes whose well-used cruelty should be masked with what is sacred and though he does not have to be pious, he needs to appear so, or else it is impossible to impose the state-ideology through the hand of the Prince. The term religion in Machiavelli's phiolosophy seems to be a broad term including the culture, the way of life and identity since the reinterpratation of religion is aimed to direct people to this world and changing their humble character to the one who is always ready to fight. The reinterpretation of religion means a molding of a culture which is compatible with the state's 'ends'.

Robinson argues that the globalization of world economy brings about the 'transnationalization of civil society and political processes', the globally integrated social life and a 'global culture' are the features of global society. 'In this view nations are no longer linked externally to a broader system but internally to a singular global social formation" (Robinson 1998, p.564).

People re-construct their identities through the impact of the circulating mass culture and especially the migrants have the chance to associate their lives, ideas, religious beliefs with that of what exists in their home countries. Dijkstra argues that each culture is gradually being mingled with motifs and features from other cultures. Today's migrants have 
better chance to resume their relation with their origins (home countries), for instance by means of temporary remigration thanks to surmounting technological transition of recent years, such as Internet, fax, mobile phones and extensive and inexpensive air travel (human flows) (Dijkstra 2001,p.59). If the migrants' original culture is not in harmony with the ideology of the nation state in which they live, they are perceived as catalyst of instability. Violent and harsh acts for stability and clever implementation of cruelty become inevitable that will be interrogated below through the culture policy of EU member states.

Though the process of globalization and deterritorialization seems to unfold the restraining mechanisms implemented by the nation-states, it is also the case that the world is still governed by small nation states whose pressure upon the 'hazardous impacts' of globalization continues. In assessment of the future of globalization, it is firstly clear in theory that "nation-state conceptualizations are incapable of explaining phenomena that are transnational in character"(Robinson 1998,p.562). Nation-states are based upon sovereignty over a territorial space and people while globalization creates a break between the states and their control over the territory. The control mechanisms for territory are also directly linked to the control mechanisms of people's ideology that should be 'in service' of the nation-state. Nation-state ideology does not hesitate to use "unscrupulous means or methods provided that they will attain the desirable political result or end" (Deutsch 2004,p.198)

\footnotetext{
"We see a transformation of the nation-state involving the evaporation of triad of territory, culture and identity. The nation-state is losing its 'naturalness'. 'National order of things'-that has been viewed in the modern West as the natural order of things-has to be problematized" (Dijkstra 2001, p.60).
}

World system is still based upon the small nation-states which inevitably get exposed to the probable impacts of globalization through circumvention. Though it is claimed by cosmopolitans or globalists that nation-states have come to the end of their terms and world community will emerge on the stage through the incessant process of deterritorialization, I argue that globalism is not a problem if it is not perceived as a problem but as a chance or milieu to embrace the growing needs of people and the solution seems to be lying in the positive responses to be given by the nation-states or the disposal of nation states adopting Machiavellian philosophy in practice. It is obvious that globalization process resulted in growing needs (cultural needs that have direct influence upon the daily lives of people) of people, and if these surmounting needs are not perceived as a threat to the state mechanism, globalization can be made use of. Machiavelli's envisioned citizens are of a mere type, whose culture, loyalty, behaviours and religion are defined by the Prince who is both powerful and good at deception. Any other type is perceived as a threat and needed to be changed in line with the state ideology. Nation-state system is the advocate of 'status quo', namely the nation-state ideology is hesitant in changing the traditional perceptions of 'threat' and that is why it is also hesitant to admit and act upon the fact that nationstates are multicultural.

\section{Globalization and EU Culture Policies: Machiavellian Nation-State Paradigm Failing a Viable Response?}

It is evident that European Union is composed of multicultural nation-states which poses a realm of interrogation and a deeper explanation of the relation between globalization and its reciprocal relationship with culture policies of nationstates. It should be taken cognizance of the fact that the clash between European Union acqui and culture policies of member states makes allusion to "political use of spectacle; maximal political benefit with minimal political risk", since member states get the maximal political benefit from the membership when it is not in clash with their nation-state ideologies (Deutsch 2009, p.202). They also have minimal political risk since they have the entity of EU membership which provides a good protector against the criticism of their culture policy deficit

"The EU's so called democratic deficit is ultimately rooted in a deeper cultural deficit"(Bennett 2001,p.109). The democratic deficit within the EU can firstly be observed through the direct elections to EP in which the number of people participating in the elections has been in a constant decrease since EU's institutions are so distant to people that they seem to have no interest in adressing to the daily lives of the people. The similar situation seems even more applicable and valid for the case of immigrants since the notion of distance stems from the culture policy of EU. The EU wants to operationalize itself through the image of 'People's Europe' though the case points out that it has not succeeded much in the envisaged project of so-called 'People's Europe' and what I want to address is the analysis of why there is a lack of 'demos' namely; the relationship between the 'want of demos' and globalization and how this situation is related to Machiavellian implementations of nation-state ideologies. It is evident that EU's policy makers viewed the globalization with its 'hazardous effects' and tried to enforce social inclusion policies in order to appease people's growing needs. The social inclusion policies were also of a "political utility" nature and were aimed to "better the political order" (Deutsche 
2009, p.191). How 'social inclusion' policies paradoxicaly end up with 'social exclusion' in terms of cultural diversity and the diminishing significance of 'eurocentrism' and 'multiculturalism' and the reasons why the two were unable to embrace the whole 'People of Europe' are the questions to be linked with Machiavellian philosophy.

Culture had not been under the competence of EU law till the 1993 Maastricht Treaty. Till then, "EU policy makers have sought to harness culture as a vehicle for promoting solidarity and social cohesion among Europeans" (Bennet 2001,p.108). To make an allusion to Machiavelli's philosophy, 'virtue not for virtue's sake but necessity's sake' is replaced with the notion of 'culture not for culture's sake but necessity's sake'. The process of globalization functions as the break between the culture 'harnessed' by the nation-state to preserve the social "integrity" of the state and the people. The Eurocentrism and its conception of culture also brought about social exclusion and intolerance towards Africans, Asians, and other categories of 'non-Europeans' who are by definition outside of the 'official European culture'(Bennet 2001, p.108) which is expressed with the words of 'laying the foundations for a destiny'(Bennet 2001,p.108). Tony Bennet makes it clear that "EU's cultural initiatives were guided by the belief that culture could be mobilized to galvanize people towards a new conception of themselves as 'Europeans' in a manner reminiscent of the model of nation-state formation"(Bennet 2001, p.110) EU member states, depending upon the support of majority depicting the European traits, did not adopt any Standard makes allusion to the Machiavellian "exploitation of human selfishness for maximum political benefit" (Deutsch 2009, p.195) It was geniunely problematic to engage in a nation-state formation method to create 'People's Europe' since nation-state formation methods overlap with "the efforts to reduce cultural diversity and thereby giving rise to imagined communities" (Dijkstra 2001, p.56). It does not take a genius to observe in Machiavelli's philosophy that the type of community envisioned is not a real but only an envisioned or imagined community. "Collective selfishness" is utilized as to pave the way for social-engineering envisioned (Deutsch 2004, p.195). The role of globalization is of utmost significance to whose effects on EU's culture policies will circumvent or respond and it will provide us with the possibility to consider the 'elasticity' of EU's policies and to what extent Machiavellian philosophy is valid.

With the aid of globalization, "new multiple and varying identities emerge" and the people reading the similar books, daily newspapers within the 'closed borders' of nation-states got exposed to new cultures through media and tourism etc.(Dijkstra 2001,p.58). Nasström's tentative view of the break between the people and the territory (as the territory of nation-state) unfolds the reciprocal relation with the words of;

"Globalization is not imagined as a pre-political community, a constituent power that is supposed to bestow legitimacy upon the state. Globalization is rather imagined as that which questions the community." (Nasström 2003,p.827)

Globalization process overlapping with the social and political integration of EU, has had a crucial impact not only on people's growing link to their own identities but also the recognition of being made a part of an 'imagined community' with which Africans, Asians and other categories of non-european people living in EU countries have no substantial connection. "The new and multiple identities emerging are no longer confined to a specific area-they are deterritorialized" (Dijkstra 2001, p.58). The process of globalization functions as the catalyst in 'opening the box of Pandora' which is replaced by the process of 'unfolded imagined community' of nation-state paradigm that does not hesitate "to change one's self / flexibility in moral behaviour" (Deutsche 2004, p.206) Eurocentrism loses its basis through the process of globalization since it bases itself on a nation-state formation method (People, Territory and Culture) in a multicultural milieu where people are deterritorialized. While globalists' view of 'dismantling nation state' and the 'emergence of global community' seem to be far distant and not overlapping with today's globalization, the view that nation-states are insufficient in responding to the cultural needs of people seem to be justified with the implementations of EU that can be interrogated in Dijkstra's words of;

"The EU does invest in the establishment of new common traditions (invented) in order to become community (imagined) but this has not led to European nation. Creating a nation does not operate on command" (Dijkstra 2001, p.68).

It is not possible to regard of a unitary national culture and community for EU since it by definition consists of multicultural societies which are reluctant to integrate themselves in as a member of 'imagined community' which has no relation or effect overlapping with the daily lives of the people. It is evident that the use of Machiavellian ruthlessness, calculated cruelty through modern forms is not adequate to form a nation state. Even if the policy-makers adopt the notion of being "pretender and dissembler, masking his actions with false words and acts that give the impression of faithfullness", it is impossible to thrash people's multifaceted identities through nation state mechanisms (Deutsch 2004, p.206) The communities forming the one part of the 'triad' are deterritorialized in the sense of identity, culture, and sense of belonging. Elden makes the point with the words of

"The cultural dynamic of deterritorialization has decoupled previous links between space, stability and 
reproduction; it has situated the notion of community in multiple locations; it has split loyalties and fractured the practices that secure understanding and knowledge within the family and social unit" (Elden 1998, p.9).

It is also evident that Machiavelli's philosophy aforementioned is of temporality. The end signifies a rule by an inspirational leader, rule of law, interest of majority and people actively participating. Though it is of a republican nature, the means utilized is of the same nature used by the member states of EU. Globalization process points out to what extent nation-state paradigms of member states show resistance against the difference emerging. Globalization process made it clear that social integration of EU cannot be envisaged through the concepts that are based on the 'sameness' implying 'the loss of one's culture'(Dijkstra 2001, p.60). "Until now EU has been using the same ideology as the national states, and the same type of problems persists if the EU uses the same arguments as the nation-states with regard to admittance, refugees may be defined even more as 'the other' or as problem of us versus them"(Dijkstra 2001,p.69). It is also evident that EU does not have any establishment concerning the cultural rights of migrants (non-citizen) or minorities (citizen but of different origin) in its acqui. There is a certain void in EU acquis adressing migrants and minorities, since it does not provide anything other than the phrase of 'respect for and protection of minorities', while the migrants are already categorized as the citizens of member-states leaving their destiny to the competence of member-states. Member states "get the ultimate political benefit with minimum political risk" as aforementioned.

What exists on a piece of paper, in philosophy, or theory does not mean that the thing exists in the real life. Machiavelli does not give any guarantee that the re-interpretation of religion will have the result of a change in the behaviours of people. What is in theory and philosophy seems not to be existing in practice. Similarly European Commission's 1996 report on EU cultural policy makes the conclusion as: 'European model of society built on a set of values common to all European societies'(European Commission, 1996:102) with the assumption of 'consensus for a European model of society that does not exist in practice'(Bennet 2001, p.117) While that phrase covers the non- existant model of society, paradoxicaly, it does not cover 'the acknowledgement of cultural diversity'(p.117) that exists in multicultural member states of EU.

Rex's article (2000) points out that the mechanism of multiculturalism is also disfunctional in theoretical sense and not responding to people's growing daily-cultural needs (real-life). Rex makes it clear by making reference to Jenkins' words when he defined the term "integration as implying not a flatenning process of uniformity, but cultural diversity coupled with equal opportunity in an atmosphere of mutual tolerance" (Koopmans 2000,p.60).

Multiculturalism appears to be included in the definition by Roy Jenkins since people's differences are "not only to be tolerated but also acknowledged as permanent and valuable and actively protected and promoted in law and public policy" (Dijkstra 2001,p.61).

Decline of national cultures through globalization process and trying to be compensated with 'multiculturalism' involves the 'transformation of culture rather than a loss of one's own culture, traditions, identities'(Dijkstra 2001, p.60).

"The rationale underlying European Union cultural policies appears to be less about celebrating difference or embracing multiculturalism, as promoting the idea of Europe's overarching unity through that diversity"(Bennet 2001,p.115).

Nation-states possessing the competence on cultural policies tend to give more value to 'union' side of the dichotomy since state-politicans tend to 'rescue gradually disintegrating society' and politicians can only enjoy the instrument of conservative cultural policies to gain the votes of nationalist citizens which is of utmost significance in explaining nation-state's unresponsive inelasticity. In paralel with what Machiavelli envisioned, 'a ruler must appear to be what his subjects want and it is indeed neccessary to appear to have them" since they need a constant popular support (Deutsche 2004, p.207).

A political order based upon the virtuous human acts is represented as a failure in Machiavelli's philosophy. Though what is virtuous in modern sense in the issue of migrants and refugees is not made evident here, what is not virtuous is formalized as the politicians' desire for power, adaption of Machiavellian methods for popular support and overwhelming of the notion of unity over diversity. The notion of 'unity in diversity' both entailing and embracing Multiculturalism ended up with the domination of unity against diversity. Furthermore, migrants or guest workers have been made a prominent discussion dominating propogandas of the national elections in member states especially by conservationist right wing parties. EU tends to forge/force a 'common heritage' that people living within the boundaries share. It is in fact a common heritage that is exclusionary. However it does not take a genius to see that culture is not non-changing or static and cannot be crystalized. The kind of religion envisioned by Machiavelli is re-interpreted but it does not necessarily mean that it can be changed any time. It can be changed when it is necessary, when it is not compatible with the state's ideology, or it is not in service of the state. The member-states of European Union adapt the protection of 'status quo' nature prevailing in nation-state ideology. Though the supranationalization in economic, political and judiciary realms has grown to a high extent, the same development is not applicable to the case of improvement of a 
common culture policy since it is perceived as a threat to the national integrity and sovereignty of the state. It is also evdent that this kind of response is in total resemblance to the other nation-states's attitudes claiming the 'preservation of the national-sovereignty and social integrity of the states' defined as the utmost and profound duty of the nation-state. What EU cultural policy also mistakes is "European cultures are engaged in a constant process of negotiation, exchange and syncretism from which new formations of culture and identity are emerging such as Turkish-Germans, FrenchVietnamese, Afro-Caribbean Britons and Italian Moroccans." Yasmin Alibhai Brown argues that 17 million Muslim live within EU but "they do not yet see themselves as a part of the project in any meaningful sense"(Bennet 2001, p.116). The type of citizen envisioned as fearful, subservient in Machiavelli's text is of its reflections on the EU citizenship visions. It is evident that EU cultural policy cannot avoid from Machiavellian notion of discarding the traits if it is not in service of the member states. On the one hand, European Union endeavours to embrace all people through the project of 'People's Europe', it is still hesitant in stripping the member-states of their competence on culture policies. Though European Union makes promises of being 'People's Europe', it fails to carry such issues of culture, migrants and visas to a supranational level. Being under the competence of each member state, culture policies reflect the typical nation-state reactions since there is not sufficient involvement of institutions of European Union. It is also evident that member states perceive culture policy as the realm of showing off their competence on national sovereignty. "It is important to see that the nation-state is not the source of the crisis, but its most plausible resolution" (Nasström 2003, p.815).

Rather than transferring the competence on culture policy, migrants and education, member states make use of these realms as the means of fostering Machivellian type of 'unity' in society. Weiss (1999) points out that states have the greatest will to transfer their competence to supranational institutions where there is the complete technical agreement on what needs to be done and where these issues are not of value for national sovereignty. Hence there is more agreement between the nation-states on the chemicals to be used in making of the air travel safety standards than tax and labour standards (that makes an allusion to 'situational ethics' since adoption of trivial EU acqui does not harm the national sovereignty) (p.71).

'The machinations of EU seem even more removed from immigrants' daily lives than from those of member state citizens" (Kourvetaris-Ireland 1996, p.132). In 2005, African origin people living in France indicated their resentment with a rebellion in the ghettos of urban cities which was a crucial way to point out that they are not only not yet see themselves as the part of the system but also criticize the European Project that has nothing to do with their social, economic, or cultural lives. Social and economic discrimination cannot be seperated from cultural identities of these people since the discrimination in the social and economic areas is only a result while their cultural identities is the implicit reason but explicitly dominating the way they are treated by the Machiavellian ideology. Significant to the point to be made followingly, it is not the reluctance of Africans or 'others' living in EU that form a clash between the system and the people, but the system (based upon politicians' view as those who get what they seek is good because what they want to get is the votes of nationalists) is the primary source of such a social disintegration. During August 2011, the clash between the European project and immigrants emerged in Britain. Britain is probably the most multicultural member state of EU however African originated people rebelled against the system where their identities are attributed to a secondclass citizenship. The absentee of 'demos' in European Parliament elections has much to do with the cultural deficit prevailing in member states and the lack of competence in law of EU. It has also much to do with the cultural, economic and social policies 'implying only flatenning process of uniformity', regardless of cultural diversity.

Favell and Geddes problematize the question of "how far the supranationalizing tendency will be institutionalized at the European level with consequent effects for migrant inclusion"(Koopmans 2000,p.422) The question is both very interesting and explanatory in regard of Amsterdam Treaty too. The 3rd pillar's unification with the 1st pillar seemed revolutionary to many experts in terms of improvement in supranationalism however it was also the case that immigrant issue was left under the third pillar along with Common Foreign and Security Policy. Morris points out the decision-taking mechanism in relation to culture policy realm with the words justifiying realists' claim of 'allowing nation-state' on the stage here.

"To date, collaboration in Europe has been framed in the context of national sovereinty. Within the formal machinery of the EU, migration issues are debated in confidential inter-governmental fora and unanimous agreement has been a precondition of any joint action." (Morris 1997, p.196)

EU and member states should dispose of their reluctance to admit that "Just as there is not one but several 'Europes' so there is no one European culture but rather a plurality of European culture". (Bennet 2001, p.119). The plurality of culture points out the plurality of people's needs in culture and social areas are to be fulfilled that have direct relation to their lives. "EU should focus on promoting cultural diversity in its own right" (Bennet 2001, p.119).

The question of 'how far EU cultural action is successful?' can be answered with Bennet's words of

"Where it has focused on small, pragmatic inventions such as town-twinning, educational exchange, the promotion 
of minority languages, enhancing public access to museums and galleries, rather than its ambitious plans to construct "European culture area." (Bennet 2001, p.119)

\section{Conclusion}

Theories of Eurocentrism and Multiculturalism and the culture policies based upon 'flattenning of diversity' derived from these theories have resulted in a break between the institutions of European Union and people of different cultural orientation; therefore these policies resulted in 'Europe of Institutions' rather than embracing People of Europe except for some small and pragmatic social milieus. It is called 'lack of demos' problem since people have grown their external socio-economic and cultural ties with their home countries or have lost their dependence upon the nation-states, thus have lost their sense of belonging to the mentality shaped by Eurocentrism and Multiculturalism. Machiavellian nation state paradigm of member states has avoided from changing their perspective on the imagined communities. The philosophy realized resulted in a cultural deficit that created the social crisis as in 2005 and 2011. The cultural deficit caused by mentioned disfunctions of nation-state paradigm of culture policies, domestic policy concerns, disfunctionality of Eurocentrism and Multiculturalism created a sense of non-belonging which created its reflection on the political arena which results in the 'lack of demos' problem in democratic procedures and "the EU so-called democratic deficit ultimately" and obviously has much to do with "deeper cultural deficit" for which the nation-states' culture policy responses are responsible (Bennet 2001, p.109).

So far it is clear that member-states' perception of culture policy is overwhelmingly shaped as the reminiscent of nation-state paradigm and, any change imposed upon the member-states on this issue is opt to create a sense of insecurity or a threat to the 'social integrity' of the country. It is the "collective selfishness" of the member states that depict the clash between the desires of different entities and the policy-makers. Machiavellian notion of modern political philosophy is based upon the notion of securitization of wide spectrum of subject such as religion, culture and identities. In paralel with that member states and the politicians tend to 'securitize' the culture policy issues when the national competence is 'lost'. EU institutions should involve in the member states' culture policies and the function of EU institutions should be 'to desecuritize' such issues, without which, it will be impossible to create 'People of Europe' which will probably result in an economic, political and acqui union but, with a seperate implementations of culture and migrants policies within the member states. European Union institutions can be successful in alienating the member states from the nation-state paradigms in culture policies by supranationalization of such policies, if not, it is difficult to distinguish the member-states of EU from classical nation-states. The second Machiavelli is also of significance in pointing out "the rule of law" on the condition that it also appeals to real/daily lives of all people in EU which has been omitted. Though his philosophy about cruelty and ruthlessness is a kind of temporal evil, it is evident that that of nation states is of a constant nature.

\section{References}

Alexander, Jeffrey. (2005)."Globalization" as Collective Representation: the New Dream of Cosmopolitan Civil Sphere",International Journal Politics, Culture, Society, 81-90.

Bennet, Tony. (2001).Differing Diversitities, Transversal Study on The Theme Cultural Policy and Cultural Diversity, 'The Cultural Policies of the European Union and Cultural Diversity',107-119.

Bislev, Sven. (2004)."Globalization, State Transformation and Public Security", International Political Science Review, 281-296.

Deutsche, Kennet L. , Fornieri, Joseph R. (2009). "An Invitation to Political Thought", Michael Rosenberg, 183-221

Dijkstra, Susan, Geuijen, Karin, Rujiter, de Rujiter. (2001). "Multiculturalism and Social Integration in Europe",International Political Science Review/ Vol.22, No.1, Management of Social Transformations, 55-83.

Elden, Stuart. (2005)."Missing the Point: Globalization, Deterritorialization and the Space of the World", Transactions of the Institute of British Geographers, 8-19.

Koopmans, Ruud, Statham, Paul, (2000). Challenging Immigration and Ethnic Relations Politics, Comparative European Perpectives, Koopmans, Ruud,

Statham, Paul 'Introduction' (1-11) Rex, John. 'Multiculturalism and Political Integration in Europe' 57-74 Favell,Adrian, Geddes, Andrew 'Immigration and European Integration'

Kourvetaris, George A. Moschonas, Andreas, (1996). The Impact of European Integration:Political Social and Economic Changes, Preager Publishers, Westport 429, Oxford University Press

Mann, Michael, (1997)."Has Globalization Ended the Rise and Rise of the Nation-State?", Review of International Political Economy, 472-496.

Morris, Lydia.(1997)."Globalization, Migration and the Nation State: The Path to a Post-National Europe?", The British Journal of Sociology, 192-209. 
Nasström, Sofia. (2003). "What Globalization Overshadows", Political Theory, 808-834

Wolf, Martin. (2001)."Will the Nation State Survive Globalization", Foreign Affairs, 178-190.

Weiss, Linda. (1999)."Globalization and National Governance: Antinomy or nterdependence?" Review of International Studies, 59-88.

Yashar, J. Deborah. (2007). "Resistance and Identity Politics in an Age of Globalization", Annals of the American Academy of Political and Social Science Science, 160-181. 